the fallacy of post hoc ergo propter hoc, and must be critically examined in that light. It has also been quite reasonably suggested that when there is perineuritis of the optic nerve, operation on the sphenoidal sinus (even if it is not diseased) may hasten recovery through the beneficial effects of the relief of local congestion and the action of neighbouring processes of repair. An heroic remedy, if this is so.

All that is left then of Miss Ford's theory, is that a very strange sort of retrobulbar neuritis, in a few cases, is alleged to have been associated with a very peculiar type of sphenoidal sinusitis, despite the opinion of the well-known rhinologists; but under such circumstances that it is very difficult-to demonstrate any connection between the two conditions, if either or both of them really existed. The whole is made plausible only by Miss Ford's technique; a few - cases, a few facts, a few disputed data; these knit together by a loose terminology make up a theory to explain away the difficulties of at least three diseases which have baffled the patient work of painstaking investigators.,

I hope this will serve to make clear my contentions, and that they will not appear prejudiced or unreasonably sceptical; if this is progress, I still prefer to wait. It is clearly profitless to labour the question, as the points of view of Miss Ford and myself are so diametrically opposed that they cannot be reconciled; we hardly speak the same scientific language. It remains only for me to retire from the controversial field, and to leave to her that latest word which is the privilege of her sex. Strive as I may to keep an open mind, I must confess that I am still unconvinced as to the possibility of closed nasal sinusitis-undetectable, and invisible to the most skilful eye-lurking in wait, and dealing out destruction in due time. Many and various, I know, are the weapons in the armoury of death and disease; but I cannot yet accept among them the sphenoidal submarine.

I am, Yours truly,

AllaN H. BRIGGS.

20; MINSTER YARD,

LINCOLN, June 11, 1942.

\title{
OBITUARY
}

\section{MALCOLM LANGTON HEPBURN}

OLD Moorfields students in many parts of the world will have learnt with great regret of the death of Malcolm Hepburn. But by those who had the double privilege of being his colleagues and of knowing him well, his loss will indeed be deeply felt. 
Malcolm Langton Hepburn was the son of Augustus Paull Hepburn, of Bermondsey. He was educated at Uppingham, and entered St. Bartholomew's Hospital in 1885, where he gained the Foster Prize in anatomy and qualified in 1892, taking the Conjoint Diploma and the M.B., B.S. degree in the University of London. $\mathrm{He}$ then served for a year as house-surgeon to his uncle Mr. Langton and added the F.R.C.S.(Eng.) and the M.D.(London) to his qualifications. In 1895 he began general practice in Lowestoft where he later was appointed Assistant Surgeon and afterwards Surgeon to the Hospital. Returning to London in 1904 he took up the special study of Ophthalmology and joined Moorfields as a student, where he worked under Sir Arnold Lawson and the late Mr. Holmes Spicer, eventually becoming Chief Clinical Assistant to Sir John Parsons. During the same period he attended St. Bartholomew's Hospital and was appointed Chief Assistant in the Ophthalmic Department:

His first Staff Appointment was that of Assistant Surgeon to the Central London Ophthalmic Hospital and soon afterwards he became Assistant Ophthalmic Surgeon to the Hampstead General Hospital. These appointments were followed by his election to the Staff of Moorfields in 1910, and in 1913 he was appointed Ophthalmic Surgeon and Lecturer to the Royal Free Hospital. At Moorfields he served as Sub-Dean of the Post-Graduate School from 1913 to 1920 and after that date as Dean, until his retirement from the active Staff in 1926 .

In addition to his other activities he examined for the D.O.M.S. Diploma, and occupied the Presidential Chair for two years at the Section of Ophthalmology of the Royal Society of Medicine. He also delivered the Doyne Memorial Lecture at the Oxford Congress in 19.35 .

At the time of his death, Hepburn was a member of the Consulting Staff of Moorfields and of the Royal Free Hospital and was also Hon. Secretary to the Council of British Ophthalmologists, a post which he had filled for a. number of years.

Malcolm Hepburn was essentially a man of sane outlook and well-balanced judgment, qualities natural to him which were no doubt enhanced by his wide experience gained in general practice.

His surgical work was on $\backslash$ a high level and he was a popular teacher, always attracting a large crowd of students.

His strong sense of duty and his great conscientiousness were salient features of his character; his patients' welfare whether in hospital or in private was his chief concern. He was always anxious to learn and was a familiar figure at meetings in the proceedings of which he not infrequently took part. A branch of ophthalmology in which he shewed special interest and on which he held original views was that concerned with inflammatory lesions of the choroid, their pathology and the fundus changes which 
characterize them; this he made the subject of his Presidential Address at the Royal Society of Medicine.

Hepburn's personal charm, his modesty, geniality and unselfishness combined with a certain sense of humour won him many friends, but in those who were privileged to know him well the chief feeling which he inspired was one of affection. He was the most loyal of colleagues and utterly incapable of a mean thought or action.

Those students who passed through Moorfields during the years of his deanship will remember gratefully the fatherly concern which he shewed in their affairs and his constant desire that they should be enabled to make the best use of their opportunities.

Hepburn was a keen sportsman and a good player of tennis, cricket and fives. But apart from his work the outstanding interest of his life was mountain climbing. 'He was a' climber of great experience and distinction, a member of the Alpine Club and a conqueror of many of the most difficult peaks in the Alpine chain. His love of the Alps amounted to a passion, a statement to which anyone who had the privilege of accompanying him to Switzerland can testify. His contributions to the subject of mountain-sickness published in the Journal of the Alpine Club were recognized by the Royal Geographical Society, of which he was elected a Fellow.

Hepburn leaves a widow, a son and three daughters.

\section{FRANCIS ANTILL POCKLEY, of Sydney}

Mr. Pockley, who had been our Sydney representative on the general Committee of the Journal since our foundation, died on July 3, 1941.

In war it is almost impossible for the Editors to keep abreast of such news, and it was not until Dr. Lockhart Gibson wrote to notify us that we knew of Mr. Pockley's death. He asked the Editor of the Med. Jl. Austr. to send us the issue of August 9, 1941, which contains appreciations from an old friend and from Dr. Lockhart Gibson. We wish to acknowledge our appreciation of this kindness as it enables us to give our readers some idea of $\mathrm{Mr}$. Pockley as a highly distinguished Australian and ophthalmologist.

Pockley was born in 1857, the son of Captain Robert Pockley, a well-known seaman of that epoch. His ancestors were Yorkshiremen, where they have been located for centuries. Pockley's mother was Miss Selina Antill, daughter of Major Antill, who was A.D.C. to. Governor Macquarie in 1809. Major Antill had served under Wellington in the Black Watch and no wonder that Pockley was proud of his lineage.

Pockley started on a business career after education at Sydney Grammar School, and later came to Edinburgh to study medicine. His academic career was one of great brilliancy. He was house 